soldiers in the Spanish-American War. Reed's team was sent to Cuba in June; their main concern was with the bacterium Bacillus icteroides, claimed by the Italian bacteriologist Giuseppi Sanarelli to be the cause of yellow fever, and they spent a month disproving this hypothesis. But in mid-July they were visited by Durham and Myers from the Liverpool School of Tropical Medicine. These workers were familiar with the recent that the infective agent passed through a bacterial filter and took 12 days to reach the infective stage in the mosquito.

But then politics took over and the controversy that developed, ostensibly a dispute over scientific credit, actually reflected a struggle for power. The defeat of Spain had not brought freedom to Cuba; the Platt amendment, which placed the country under the safeguard of the United States, humiliated the

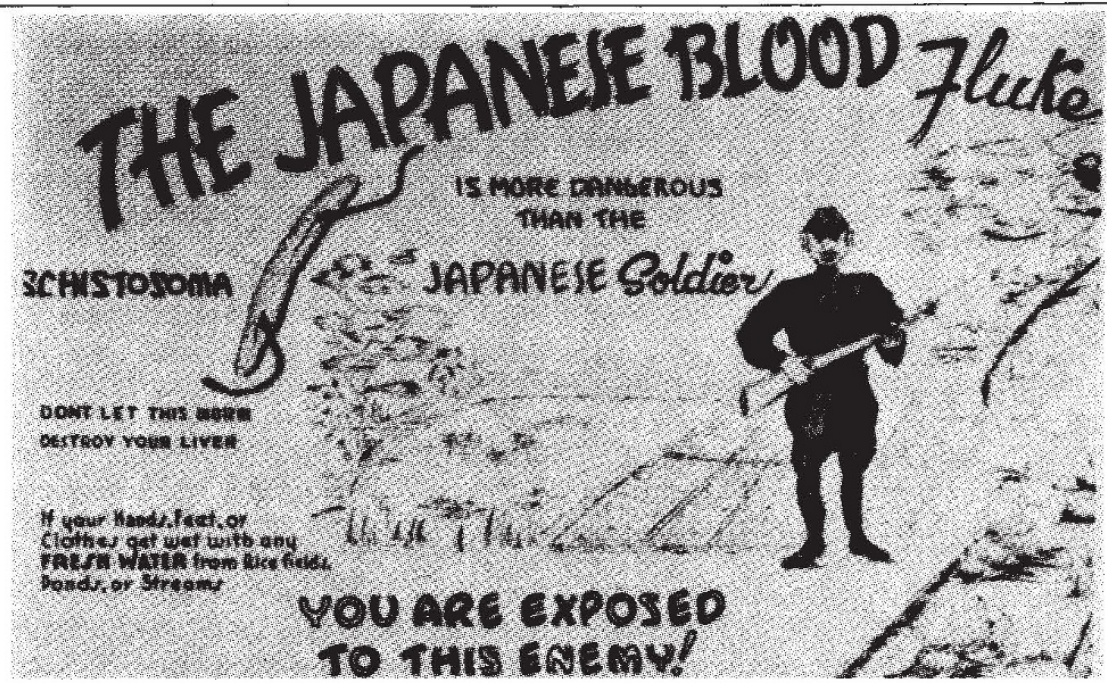

Second World War US Army poster warning of bilharzia - another debilitating tropical disease caused by parasitic worms. From Bilharzia: A History of Imperial Tropical Medicine by J. Farley. Published by Cambridge University Press, $£ 40, \$ 59.50$.

discoveries of Charles Laveran and Ross that the malaria parasite used the mosquito as an intermediate host, and took time to complete its cycle in the insect. They also knew from W. S. Carter in New Orleans that there was an interval of 2-3 weeks between primary and secondary cases of yellow fever, and in a report published in the British Medical Journal in 1900 they wrote: "This curious and somewhat prolonged interval is suggestive of a development of the infective factor in or about some agent or matter in the domicile. ... The suggestion propounded by $\mathrm{Dr}$ C. Finlay of Havana some twenty years ago, that the disease was spread by means of mosquitoes hardly appears fanciful in the light of recent discoveries in ague convection. .

The US team took action immediately. On 1 August, Reed, James Carroll and Jesse Lazear went to Finlay and obtained the eggs of his Culex mosquito. Reed was recalled to Washington, and the first, not very well controlled trials with mosquitoes were made by Lazear. Carroll was bitten on 27 August by an insect that had been fed on a yellowfever patient on the second day of illness and that had been kept for 12 days; he had a sharp attack of fever. The rest of the story is well known - Lazear was bitten accidentally and died, and Reed took charge and showed conclusively
Cuban people and opened their eyes to the meaning of US intervention - the United States had supplanted Spain. The names of Reed and Finlay became convenient symbols for a clash of values, and mythical, political versions of the discovery were spread through the media. The two official pictures painted to celebrate the discovery, by Estevan Valderrama in Cuba and by Dean Cornwell in the United States, depict not real events but fictions.

Delaporte's study provokes thought as to the real origins of successful ideas. The translation from the French is good and retains a Gallic flavour with few hiccups. But you can't help feeling sorry for Finlay. Eccentric, devious and a bit of a showman, he had the brilliant, original conception of the mosquito as a vector but had no way of seeing it as a second host. With a little more luck, or a little less care, he might have kept one of his mosquitoes for a few more days: medical science would have been advanced 20 years; Finlay would have the credit; a Cuban volunteer, not Lazear, would have been martyred; and there might never have been a Walter Reed Army Institute of Research in Washington DC.

Len Goodwin (formerly with the Wellcome Trust) is at Shepperlands Farm, Park Lane, Finchampstead, Wokingham, Berkshire RG11 4QF, UK.

\section{Room at the top}

\section{John W. Galloway}

The Outer Cycle: Women in the Scientific Community. Edited by Harriet Zuckerman, Jonathan R. Cole and John T. Bruer. Norton: 1991. Pp. 350. \$24.95.

WOMEN feature much less prominently in science than men. This book, a collection of research papers and reviews, sets out to tell us why.

Of course, this lack of prominence is hardly peculiar to science - it is broadly true of most public and creative walks of life. But science at its best should surely subvert the established social order and lean towards enfranchisement. To find it apparently so reactionary in this respect is a bit disturbing. The phenomenon is a ready subject for sociological analysis, an opportunity that has here been enthusiastically embraced.

What exactly is the phenomenon that the authors explore and try to explain? One of their concerns is the consistent paucity of women in science's upper reaches. Women form only two to three per cent of the membership of any number of national academies of science (although in the United States the proportion is now rising and has reached a heady four-and-half per cent). And so it is perhaps not unexpected that the proportion of women Nobel science prize winners is about the same. The figure rises a little if you throw in the prizes for literature and peace. Further, the deficit cuts across social barriers. For example, in the United Kingdom there are few women Fellows of the Royal Society or women Judges. Yet Fellows represent a complete spectrum of social origins, whereas judges are drawn mainly from the better-off classes. So in this regard at least, women do seem to be sisters under their skins.

The other concern of the authors is that this low showing is not simply a result of not enough women entering science to begin with. The other day I visited a large Scottish cancer-research laboratory. Women clearly outnumbered men among the research staff. But the women tended to be young and the older staff tended to be men. In general, and this is largly the issue that the book addresses, women as a whole do progressively less well the higher up the scientific hierarchy you look - they publish less, achieve less and get paid less than their male counterparts. Similarly, in the United Kingdom, those educated at independent schools do better the further up they are in the legal hierarchy. 
There is plenty of evidence here (as there is elsewhere) for the poor showing of women in the scientific community, such as that provided in a comprehensive review by Harriet Zuckerman. But explanations for why they have such a peripheral status are thinner on the ground. Indeed, one of the book's strengths is the number of possible explanations that it turns upside down simply with relatively trivial observations.

\section{Families}

To take an obvious example, women with families use more of their energy in looking after their families than do men with families - as a consequence, men have more energy to spend on their research. But women with families are no less productive as researchers than are women without. The book might have added that many (perhaps all) of the most successful women scientists have or have had families. Dorothy Hodgkin in Who's Who lists her hobby as 'children'.

Historically, attitudes of men scientists towards women scientists were blatantly discriminatory. The treatment of Marie Curie by the French Academy of Sciences is as striking an example as any. She would have been the first woman member, but was not elected, despite having been a Nobel prize winner, as well as the first woman to hold a doctorate in France and be a professor at Sorbonne. Dorothy Hodgkin, even though a Fellow of the Royal Society at the age of 37, was denied membership of the University of Oxford's men-only chemical club, the Alembic. In any case, it took the Royal Society about 250 years to elect its first woman members. Even the US National Academy of Sciences took 63 years. And several well-known physicists, such as J. J. Thompson, Louis de Broglie and R. A. Millikan, are on record for having found it impossible to take women seriously as scientists. Of course, there might have been the odd woman who had a special scientific gift, but then in making this concession there was also the implication that pigs might fly.

But today things are different, aren't they? The formal barriers to women achieving success in science have all gone. Or do they still exist in the form of an "invisible obstacle race", as Joan Mason recently described it in Nature (353, 205; 19 September 1991)? It is a situation reminiscent of the abolition of slavery or the opening up of higher education to the working classes. Things are better, but nothing like as good as they ought to be. Those apparently being given opportunities do not seem to be able to take advantage of them.

We are obviously in the midst of a historical process, and an evolutionary analogy might be apt. Does the system discriminate against women simply because they are rare? The book provides evidence that this is so: unlike their male counterparts, women scientists tend to cite other women's papers. Also, as is made clear, women prefer some sciences to others, being much more oriented towards biology, psychology and sociology than to the mathematical or physical sciences (most mouse geneticists are women).

It is probably significant, therefore, that in the Royal Society, where cognitive psychology claims only about four fellows, two of them are women. How heavily is sociology represented in national academies of science? Medicine was the first 'science' in which women started to make substantial inroads, beginning in the 1840 s in the United States and happening 30 years later in the United Kingdom, and academic medicine must be the science in which women are most strongly represented. The medical profession seems to have been less discriminatory or to have mended its ways well before other professions, probably because of pressure by women for equal opportunities and a demand by other women to be treated by female doctors. Surveys in the United States, reported in the book, indicate that women who want to study medicine have not been discriminated against for the past 60 years. If there are fewer women in medicine it is because fewer have wanted to be in the profession. Of course, that raises another question, why don't they?

\section{Differences}

The book has some interesting things to say but it has a serious weakness. It gives little impression of what the business of being a scientist really entails. And given that the book's central thesis is that for an answer one must look to the structure of science as a social organization rather than to biology, I would have liked a much better feel for that structure. This is tied up with the fact that different sciences really are very different from one another: although the way in which women fare is in many respects similar among different sciences, there is no escaping the very real differences. This point is little more than touched on.

Although I now feel better informed to tackle the question of why there are so few successful women in science, I do not really feel much the wiser. Without doubt the lack of women in the scientific community is a very real phenomenon

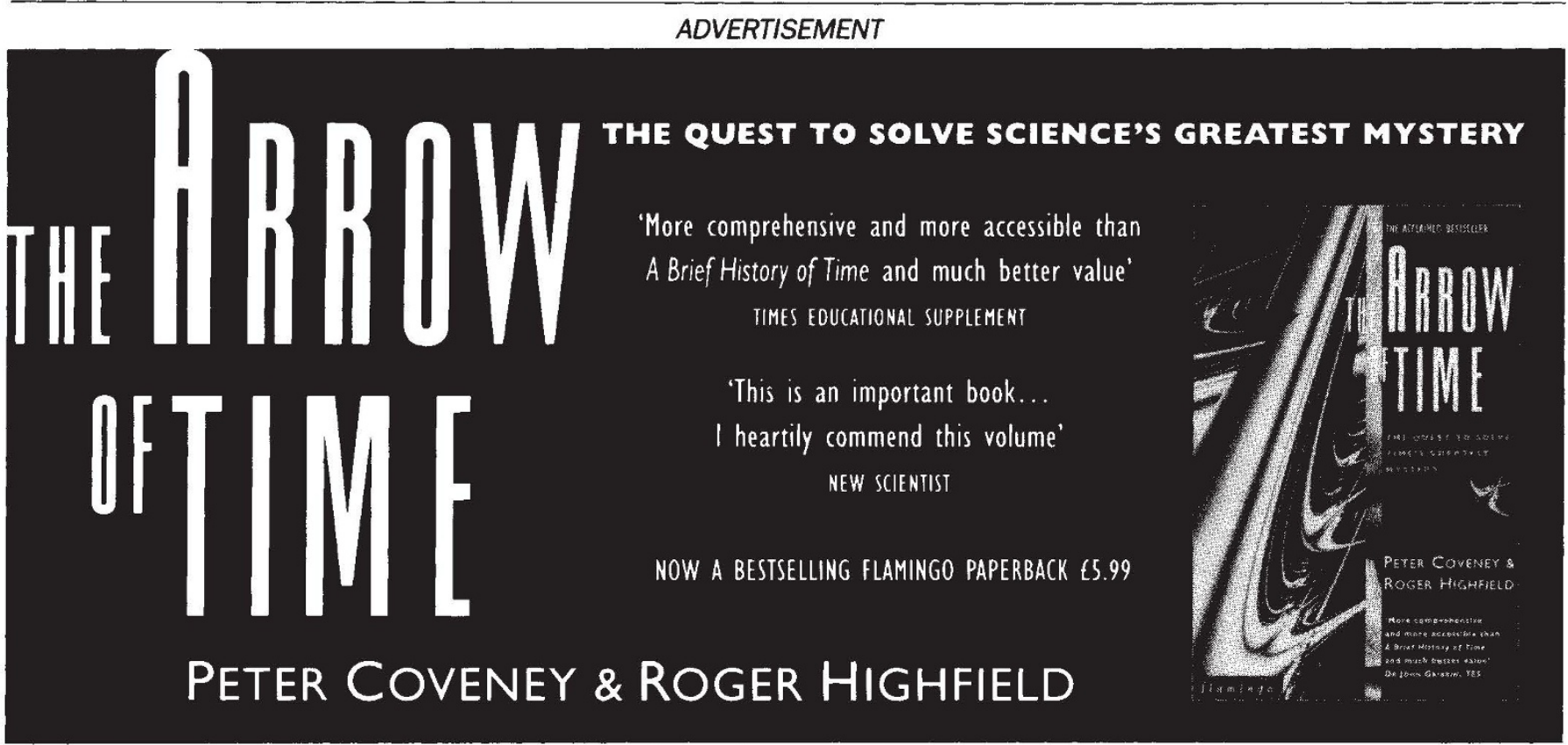


and one that is unfortunately rather refractory to change. Indeed it is so concrete and robust that you feel there must be a readily and well-defined cause. Perversely, the book's message is that there isn't.

John W. Galloway (formerly at the Cancer Research Campaign) is at the Nuffield Foundation, 28 Bedford Square, London WC1B 3EG, UK.

\section{Rewriting the future}

\section{Walter Gratzer}

Great Mambo Chicken and the Transhuman Condition: Science Slightly Over the Edge. By Ed Regis. Viking: 1991. Pp. 199. £16.99.

The Virgin and the Mousetrap: Essays in Search of the Soul of Science. By Chet Raymo. Viking: 1991. Pp. 308. \$18.95.

THE trouble with progress, as the philosopher said, is that it goes on too long. Ed Regis's excellent vade-mecum to the wilder shores of science gives evidence enough to chill your gizzard for the truth of this proposition. Here you will learn about plans for hijacking and populating comets as our world grows less friendly and more crowded, for moving the Earth into a more hospitable orbit by extending solar sails into space to gather thrust from sunlight and, since vaulting ambition may as well o'erleap itself as not, for transforming the system of sails into a nuclear fusion engine, powerful enough to move the Sun itself. A Harvard professor of physics develops a grand unified theory (or GUT) that he believes to fit the facts at last and finds to his ineffable dismay that it implies the instability of the proton; so in a space of $10^{31}$ years atomic matter will collapse like an underdone soufflé. Gloom and despair take possession of him - but never fear, for Freeman Dyson is at hand with a wheeze: all we need do is to generate a huge, cosmic energy flux (easily encompassed by turning a lot of matter into radiation) that will split open the closed Universe like a seed-pod, and then the collapse will be offset by endless expansion in another direction. (Dyson anyway does not hold with the idea of a closed Universe, which gives him, he says, a feeling of claustrophobia.)

\section{Achieving immortality}

Or we could tinker a little with our DNA and rewire ourselves for life at the nearabsolute zero of outer space. We might even learn to hibernate, and then our periodic moments of consciousness would seem, thanks to our arrested metabolism, like an eternity. James Thurber had a similar apprehension: "I'm sixty-three", he wrote to his publisher when he was sixty-three "and I guess that puts me in with the geriatrics, but if there were fifteen months in every year, I'd only be forty-three."

You may of course take the view that the future, when Earth is but a star that once had shone, can be left for your grandchildren to trouble themselves about, but, in California at least, the opinion seems to have taken hold that death is discretionary. There is, for instance, the alternative course of having your head detached and preserved in liquid nitrogen until such time as the trifling problems that still stand in the way of growing a disease-proof body from the neck down have been overcome. Cephalariums, full of bubbling vats of heads, already clutter the western seaboard. Some 25 years ago, as Regis reminds us, a paper appeared in this very journal with the good news that a cat brain, brought to room temperature after six months in the freezer, at once began to put out electrical signals little different from those generated by the living cat.

But stay: if you wait until you die or rather deanimate, in the language favoured by the believers - before suffering your head to be frozen, then you may not be in your mental prime when the last trump sounds and you rise from the nitrogen. The jazz musician Eubie Blake remarked on his hundredth birthday that if he had known he was going to live so long he would have looked after himself better. Well, no need to lose sleep over such dilemmas because less conservative thinkers, such as Professor Moravac, will tell you that freezing heads is yesterday's technology. The reason, you ask? Why, because nanotechnology is around the corner, and 50 years from now, perhaps less, there will be molecular robots to surge through your brain, neuron by neuron, reading off stored electrical signals. A year or two's work will suffice to 'download' the contents of your brain onto disc, and then you may live for eternity, in a body with the form, materials and colours of your choice, experiencing by way of appropriate inputs all the sensations you desire, from the perpetual orgasm that is said to feature prominently on the Muslims' agenda for paradise, to irrigating your tonsils with bounteous tides of Chateau Yquem. Nor will your immortality be tried by earthquakes or nuclear explosions, for backup copies of your disc - of you - will repose in safe places around (or beyond) the world.

If progress depends, as George Bernard Shaw suggested, on the unreason- able man, you will find the whole galère in Regis's pages. Here is virtuoso science writing of rare vigour and mastery; and for those who enjoy being frightened it eclipses Mary Shelley and her Gothic nightmares. If, however, you find Regis's supercharged style too wearing in large doses, then perhaps Chet Raymo is your man. He is a professor of astronomy and columnist in the Boston Globe, and the essays gathered in his new volume are polished, civilized and literate discourses on a wide spectrum of scientific topics.

\section{Selfish genes}

Raymo is captivated by the night sky and enchanted with the Escherichia coli to which we are hosts - on so generous a scale indeed that your gut contains, as he calculates, as many as would stretch from Boston to San Francisco. He ranges from Aristarchus and the astronomy of the ancients to selfish genes and the anthropology of the Yanomano Indians of the Amazon, who slaughter each other with no compunction in the interests of sex; homicidal males are rewarded by more wives and many more progeny than pacifists. Are these, Raymo wonders, behavioural genes in action?

Raymo mourns the passing of Rube Goldberg, whose concerns, it seems, transcended those of our nearest British counterpart, Heath Robinson (the man who devised such aids to good living as a machine for the removal of gravy stains from gravel drives). For Goldberg warned against the "gadget-strewn paths of civilisation", among which Raymo numbers nuclear power stations and the monstrous products of the Star Wars programme. There are 21 essays in this collection, all of them cunningly crafted and a pleasure to read, even if here and there the social concern (not to say the PC usage) is laid on a touch too liberally. Raymo is drawn to the philippics of Chargaff, whose apocalyptic visions of a society in thrall to the new genetics find little resonance in the imaginations of other biologists. And you may also stub your toe on an occasional abomination such as "person year" (it followed for me a recent sighting in this country of a ploughperson's lunch); but perhaps one can blame such lapses on a malign subeditor.

Walter Gratzer is in the MRC Muscle and Cell Motility Unit, King's College, Drury Lane, London WC2B 5RL, UK.

\section{Spring Books}

Nature's next review supplement will be Spring Books, which will appear in the 16 April 1992 issue. 